Research Article

\title{
The Design and Optimization of GaAs Single Solar Cells Using the Genetic Algorithm and Silvaco ATLAS
}

\author{
Kamal Attari, Lahcen Amhaimar, Ali El yaakoubi, Adel Asselman, and Mounir Bassou
}

Optics \& Photonics Team, Faculty of Science, Abdelmalek Essaadi University, Tetuan, Morocco

Correspondence should be addressed to Kamal Attari; attari.kamal@gmail.com

Received 10 May 2017; Revised 6 August 2017; Accepted 29 August 2017; Published 12 November 2017

Academic Editor: Srinivas Devayajanam

Copyright (c) 2017 Kamal Attari et al. This is an open access article distributed under the Creative Commons Attribution License, which permits unrestricted use, distribution, and reproduction in any medium, provided the original work is properly cited.

\begin{abstract}
Single-junction solar cells are the most available in the market and the most simple in terms of the realization and fabrication comparing to the other solar devices. However, these single-junction solar cells need more development and optimization for higher conversion efficiency. In addition to the doping densities and compromises between different layers and their best thickness value, the choice of the materials is also an important factor on improving the efficiency. In this paper, an efficient single-junction solar cell model of GaAs is presented and optimized. In the first step, an initial model was simulated and then the results were processed by an algorithm code. In this work, the proposed optimization method is a genetic search algorithm implemented in Matlab receiving ATLAS data to generate an optimum output power solar cell. Other performance parameters such as photogeneration rates, external quantum efficiency (EQE), and internal quantum efficiency (EQI) are also obtained. The simulation shows that the proposed method provides significant conversion efficiency improvement of $29.7 \%$ under AM1.5G illumination. The other results were $J_{\mathrm{sc}}=34.79 \mathrm{~mA} / \mathrm{cm}^{2}, V_{\mathrm{oc}}=1 \mathrm{~V}$, and fill factor $(\mathrm{FF})=85 \%$.
\end{abstract}

\section{Introduction}

Direct band gap materials prove that the use of an optimum configuration leads to a highly functional single- or multiple junction solar cells. The interest in GaAs solar cells has become more popular in the recent years due to its band gap $(1.42 \mathrm{ev})$ close to the standard spectrum [1]. However, its major problem was the surface recombination rate that has been reducing the GaAs solar cells improvement's start with $10 \%$ [2]. This problem was solved by means of using a Ga1-xAlx on the surface of GaAs [3]. Using GaAs junction only is not enough to get higher efficient solar cells. In fact, the improvement of its performance will surely be accomplished by adding other material layers on the top and bottom of the junction. For instance, a wider band gap material such as AlGaAs used as a back surface field (BSF) makes a significant improvement $[4,5]$. Also under the same cell configuration, the use of $\operatorname{In}_{0.5}\left(\mathrm{Al}_{0.7} \mathrm{Ga}_{0.3}\right)_{0.5} \mathrm{P}$ material increases the efficiency by $6 \%$ compared to other materials thanks to its high photogeneration rate material [6]. The GaAs solar cell has greater electron saturation velocity and higher electron mobility compared with silicon solar cells [1].
This solar cell has achieved an accurate success of around 20-25\% [7]. Recently, the single solar cells performance made a significant growth, an efficiency of $27 \%$ was recorded for the GaAs single cells [8]. A detailed set of simulated material parameters used in our design has been taken from previous publication [9-11]. The purpose of this work is to design a single solar cell based on GaAs that is highly efficient and to investigate its performance. Moreover, an optimization technique has been performed and proposed. A presentation and comparison of obtained results to similar solar devices from recent publication have been done. This work is organized as follows: an introduction of the model solar cell is taking place in Section 2. Section 3 explains the genetic algorithm of solar cells. The ATLAS simulation and the method of the proposed results are elaborated in Section 4. The last section concludes the whole work.

\section{Solar Cell Modeling}

In order to model a high efficiency single solar cell, it is important to start with similar cells of well-known characteristics and obtained performances to verify the accuracy of our 
TABLE 1: Standard parameters used in this solar cell design.

\begin{tabular}{lccc}
\hline Material & GaAs & InAlGaP & AlGaAs \\
\hline Band gap Eg $(\mathrm{eV})$ at $300 \mathrm{~K}$ & 1.42 & 2.3 & 5.65 \\
Lattice constant $\alpha(\AA)$ & 5.65 & 11.7 & 5.64 \\
Permittivity $(\mathrm{es} / \mathrm{eo})$ & 13.1 & 4.2 & 11.0 \\
Affinity $(\mathrm{eV})$ & 4.07 & 2.85 & 4.1 \\
Heavy e- effective mass $\left(m_{e}{ }^{*} / m_{0}\right)$ & 0.06 & 0.64 & 2.4 \\
Heavy h+effective mass $\left(m_{h}{ }^{*} / m_{0}\right)$ & 0.5 & 2150 & 0.62 \\
e- mobility MUN $\left(\mathrm{cm}^{2} / \mathrm{V} \times \mathrm{s}\right)$ & 8800 & 141 & 2000 \\
h+ mobility MUP $\left(\mathrm{cm}^{2} / \mathrm{V} \times \mathrm{s}\right)$ & 400 & $1.20 E+20$ & 138 \\
e- density of states $\mathrm{NC}\left(\mathrm{cm}^{-3}\right)$ & $4.7 E+17$ & $1.28 E+19$ & $4.35 E+17$ \\
h+density of states $\mathrm{NV}\left(\mathrm{cm}^{-3}\right)$ & $7.0 E+18$ & $1.00 E-09$ & $8.16 E+18$ \\
Lifetime (el) $(\mathrm{s})$ & $1.00 E-09$ & $1.00 E-09$ & $1.00 E-09$ \\
Lifetime (ho) $(\mathrm{s})$ & $2.00 E-08$ & & $2.00 E-08$ \\
\hline
\end{tabular}

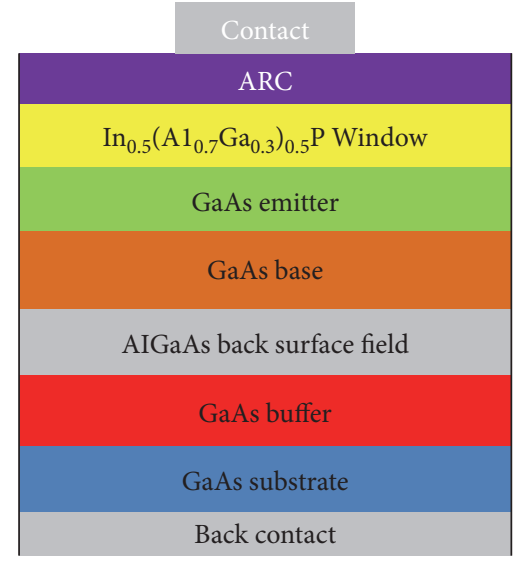

FIGURE 1: Schematic diagram of single solar cell structure used in the initial design.

model. Based on their various advantages such as absorbing a higher quantity of light, several materials were chosen and detailed in Table 1. The objective of this work was at first to construct a solar cell and then improve its efficiency. For a first step using TCAD Silvaco software, an ATLAS code was then prepared to build this structure made up of a gold contact placed at the top of the structure, and then under that was the $\mathrm{Si}_{3} \mathrm{~N}_{4}$ antireflective coating (ARC) then the InAlGaP window layer, under that was the $n$-type GaAs emitter, then a $p$-type GaAs base, AlGaAs back surface field (BSF), GaAs buffer, GaAs substrate, and finally a gold contact in the bottom of the cell. A schematic of this model is designed in Figure 1. The solar cell was illuminated by a spectral illumination source of AM1.5G as shown in Figure 2. ATLAS solves Poisson's equation; carrier continuity equations for both electrons and holes were solved, the driftdiffusion transport model. Refractive index of each material and important parameters for the simulation of solar cells are obtained from $[9,10,12]$ and from the Sopra database

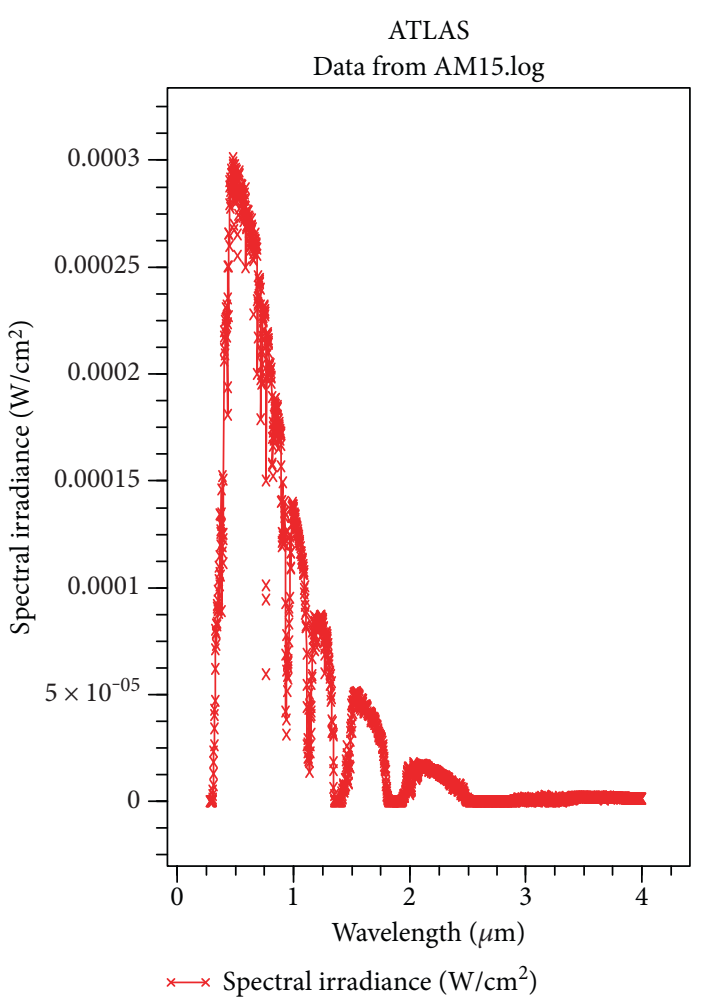

Figure 2: Solar spectrum AM1.5G.

incorporated in Silvaco. Different physics models were used to calculate recombination and carrier mobility for a solar cell structure. The Shockley-Read-Hall (SRH) recombination models and the concentration-dependent low-field-mobility model (CONMOB) are used to model the doping-dependent low-field motilities of electrons and holes. To consider bulk and interface recombination velocities, (Auger) models are also utilized.

To determine the solar cell efficiency, it is important to use the following parameters: the open-circuit voltage $\left(V_{\mathrm{oc}}\right)$, 


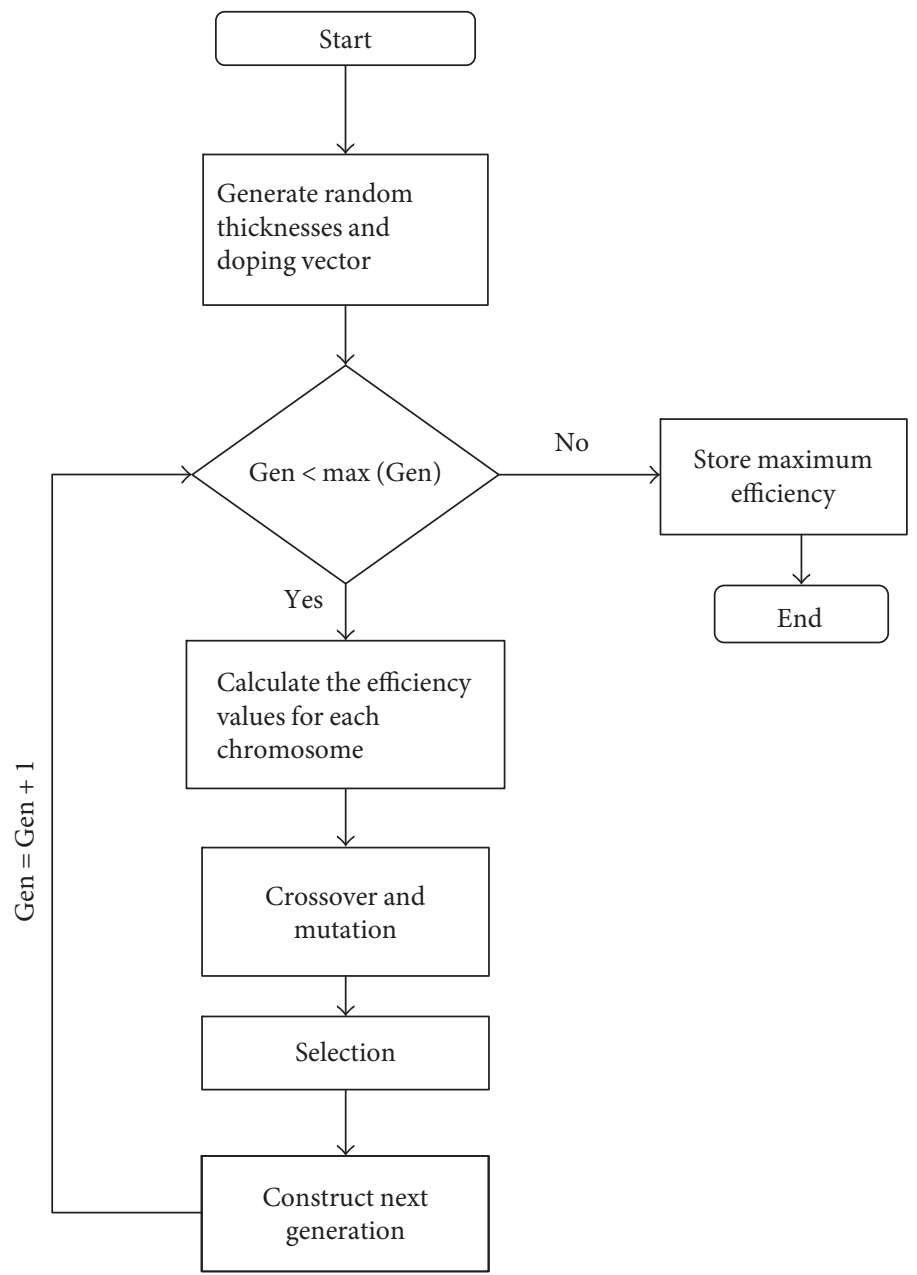

FIGURE 3: Flowchart of genetic algorithm.

short-circuit current $\left(I_{\mathrm{sc}}\right)$, and fill factor $(\mathrm{FF})$ in the ATLAS design code.

$$
I=I_{0}\left[\exp \left(\frac{q V}{n k T}\right)-1\right]-I_{\mathrm{L}},
$$

where $I_{\mathrm{L}}=$ light generated current.

$$
V_{\mathrm{oc}}=\left(\frac{n K T}{q}\right) \times \ln \left(\frac{I_{\mathrm{L}}}{I_{0}}\right)+1 .
$$

The short-circuit current $\left(J_{\mathrm{sc}}\right)$ is the maximum current available from a solar cell, and this occurs at zero voltage.

The expression for the FF can be determined empirically as [9]

$$
\mathrm{FF}=V_{\mathrm{oc}}-\ln \left(\frac{V_{\mathrm{oc}}+0.72}{V_{\mathrm{oc}}+1}\right)
$$

The maximum power is converted solar energy (solar spectrum) to electricity and can be calculated as follows:

$$
P_{\max }=V_{\mathrm{oc}} \times J_{\mathrm{sc}} \times \mathrm{FF}
$$

Based on the above parameters, we can get the efficiency of a solar cell calculated as

$$
\eta=\left(\frac{V_{\mathrm{oc}} \times I_{\mathrm{sc}} \times \mathrm{FF}}{P_{\mathrm{in}}}\right),
$$

where $P_{\text {in }}$ is the input power.

$$
G=\eta_{0} \times\left(\frac{p \lambda}{h c}\right) \times \alpha \exp (-\alpha y)
$$

with $G$ as the photogeneration rate; $P$ is the cumulative effects of reflections, transmissions, and loss due to absorption over the ray path; $y$ is the relative distance for the given ray; $h$ is Planck's constant; $\lambda$ is the wavelength; $c$ is the speed of light; and $\alpha$ is the absorption coefficient calculated for each set of $(n, k)$ value. $\eta_{0}$ is the internal quantum efficiency, which represents the number of carrier pairs generated per photon pairs. 


\section{Proposed Algorithm for Efficiency Optimization}

The genetic algorithm (GA) is generally an optimization method that allows to obtain helpful solutions to complex problems [13]. The GA has a small computing time and good convergence that makes it a powerful optimization tool. In many published classical techniques, a variable layer (thickness or doping intensity) varies by affecting random values until achieving a higher efficiency, then move to the next variable and perform the same operation. However, in our method, all variables are tested simultaneously and result to an ideal junction configuration to produce higher efficiency. A random selected binary 8 bit strings constitute the initial generation of chromosomes. The Silvaco code is called by the GA in order to get the needed data that is encoded and then exposed to some evolution mechanisms like crossover and mutation then used as chromosomes to build the next generation. In a second step, these values are decoded then written into Silvaco ATLAS code to construct the new solar cells with the new configuration. After the simulation of all chromosome generations, child chromosomes were created from the best performing parent chromosomes. The junction layer optimization process includes the window, emitter, base, BSF, buffer, and substrate layers and determines the best thickness and doping of each layer. The flowchart of GA used for optimizing the efficiency is shown in Figure 3.

\section{Results and Discussion}

In this section, two steps are performed, the first one is an initial single-structure solar cell designed and simulated using Silvaco ATLAS as shown in Figure 1. The second step consists of using the GA technique to compare the cell performance parameters with an optimized solar cell.

In the first ATLAS simulation, the layer configuration were adjusted as follows: the window thickness was $400 \mathrm{~nm}$, the emitter thickness was $200 \mathrm{~nm}$, the base thickness was $2 \mu \mathrm{m}$, the BSF thickness was $400 \mathrm{~nm}$, the buffer was $100 \mathrm{~nm}$, and the doping concentrations for these layers are $7 \times 10^{17}$, for the emitter $2 \times 10^{18}$, the base $4 \times 10^{18}$, the BSF $5 \times 10^{18}$, and the buffer $4 \times 10^{18}$. The obtained results were extracted from the $I-V$ curve characteristics for the model as shown in Figure 4, The open-circuit voltage $\left(V_{\mathrm{oc}}\right)$, short-circuit current $\left(I_{\mathrm{sc}}\right)$, fill factor $(\mathrm{FF})$, and the efficiency of this initial simulation were found, respectively: $V_{\mathrm{oc}}=1.08 \mathrm{~V}, J_{\mathrm{sc}}=22.88 \mathrm{~mA}$, $\mathrm{FF}=84$, and $\eta=21 \%$. A maximum power can be observed in Figure 5 with a value of $21 \mathrm{~mW} / \mathrm{cm} 2$. Table 2 summarizes the different thicknesses and doping concentrations for the initial model.

The next results exposed the optimization process. The simulation was done after several data exchange, between the genetic algorithm and the Silvaco ATLAS code in addition to data evaluation and generation optimization. In the end of simulation, a higher conversion of a $29.7 \%$ efficiency was recorded after a small-time computation, compared to the initial structure which has an efficiency of $21 \%$, and new layers configuration were set to construct a new optimized GaAs single solar cells as shown in

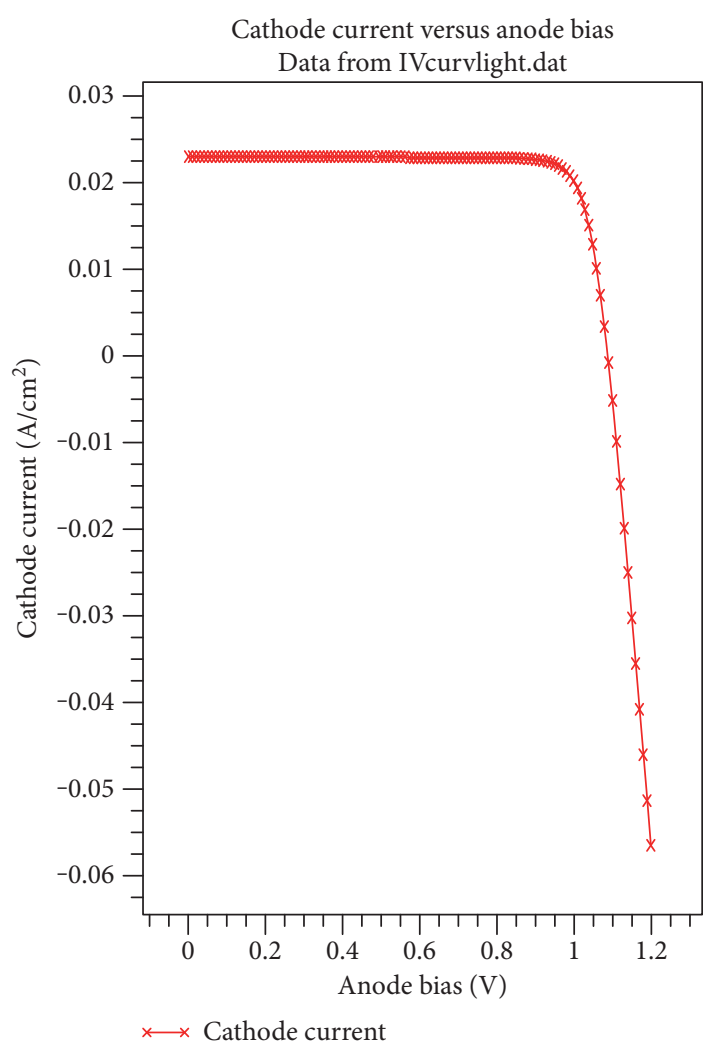

Figure 4: $I$ - $V$ characteristics of the initial model.

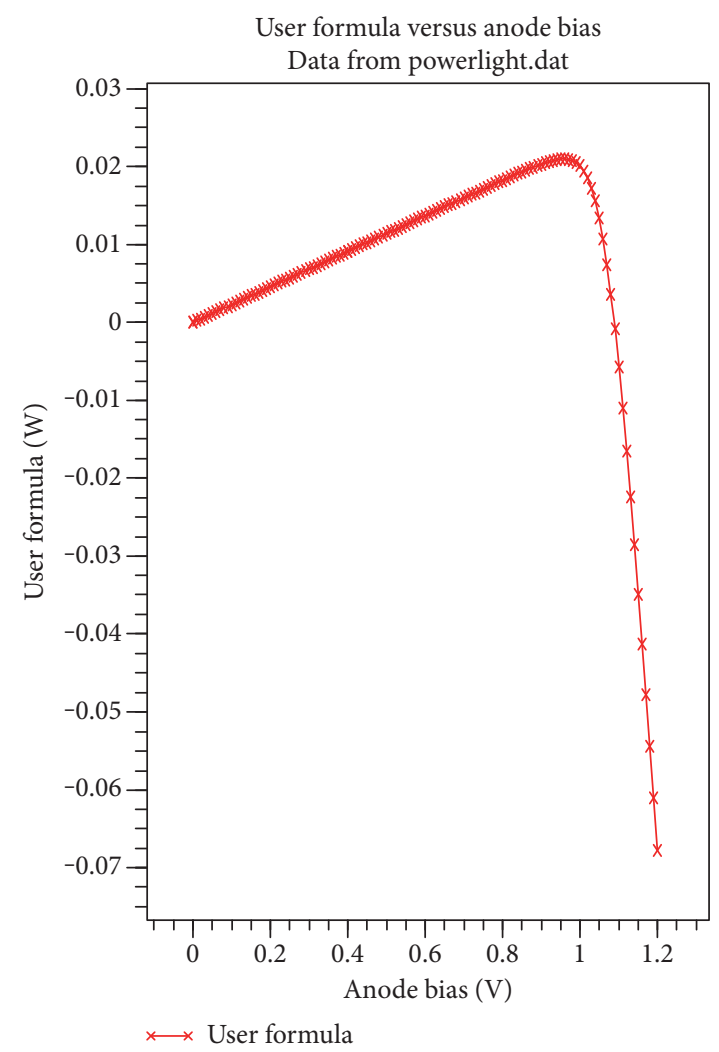

Figure 5: Power curve of the model of the initial solar cells. 
TABLE 2: Doping and thicknesses of the initial structure.

\begin{tabular}{lccc}
\hline \multicolumn{2}{l}{ Origin model solar cell } & Doping $\left(\mathrm{cm}^{3}\right)$ & Thickness $(\mu \mathrm{m})$ \\
\hline ARC & $\mathrm{Si}_{3} \mathrm{~N}_{4}$ & - & - \\
$n$-layer & $\mathrm{In}_{0.5}\left(\mathrm{Al}_{0.7} \mathrm{Ga}_{0.3}\right)_{0.5} \mathrm{P}$ & $7 \mathrm{e}+017$ & 0.04 \\
$n$-layer & $\mathrm{GaAs}$ & $2 \mathrm{e}+018$ & 0.2 \\
$p$-layer & $\mathrm{GaAs}$ & $4 \mathrm{e}+018$ & 2 \\
$p$-layer & $\mathrm{AlGaAs}$ & $5 \mathrm{e}+018$ & 0.4 \\
$p$-layer & $\mathrm{GaAs}$ & $4 \mathrm{e}+018$ & 0.02 \\
\hline
\end{tabular}

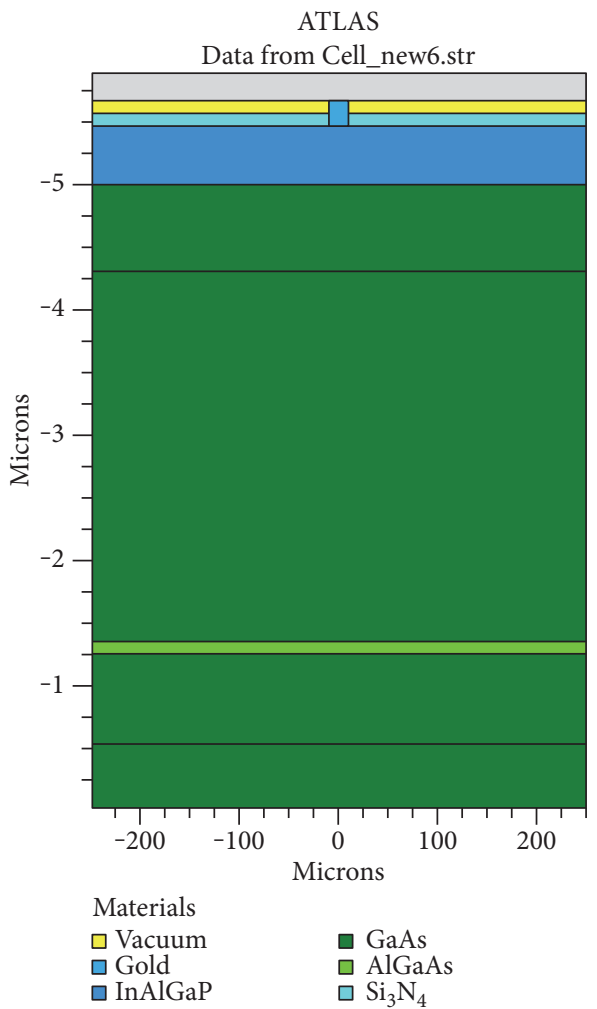

Figure 6: Final GaAs optimized structure.

Figure 6 enabling to produce a higher maximum power, its value achieved $29 \mathrm{~mW} / \mathrm{cm}^{2}$ as can be seen in Figure 7 under the AM1.5G illumination. The simulation parameters are also documented in Table 3. The optimized performances parameters, comprising the $J_{\mathrm{sc}}, V_{\mathrm{oc}}, \mathrm{FF}, I_{\max }$, $V_{\max }$, and $P_{\max }$, were found from the results of the GA and their values are listed in Table 4.

Figures 8 and 9 demonstrate the $I-V$ curve of the optimized single-junction structure using the Silvaco and the genetic algorithms, although reached-optimized cell output parameters are listed in Table 4. Moreover, a comparison between the optimized and the initial solar cells can be observed in Figure 10, as well as results comparison with corresponding theoretical and experimental results for similar studies. Our GA-proposed simulation gives good result with high-efficient performance than others introduced in various previous studies as discussed elsewhere [14-17]. Differences

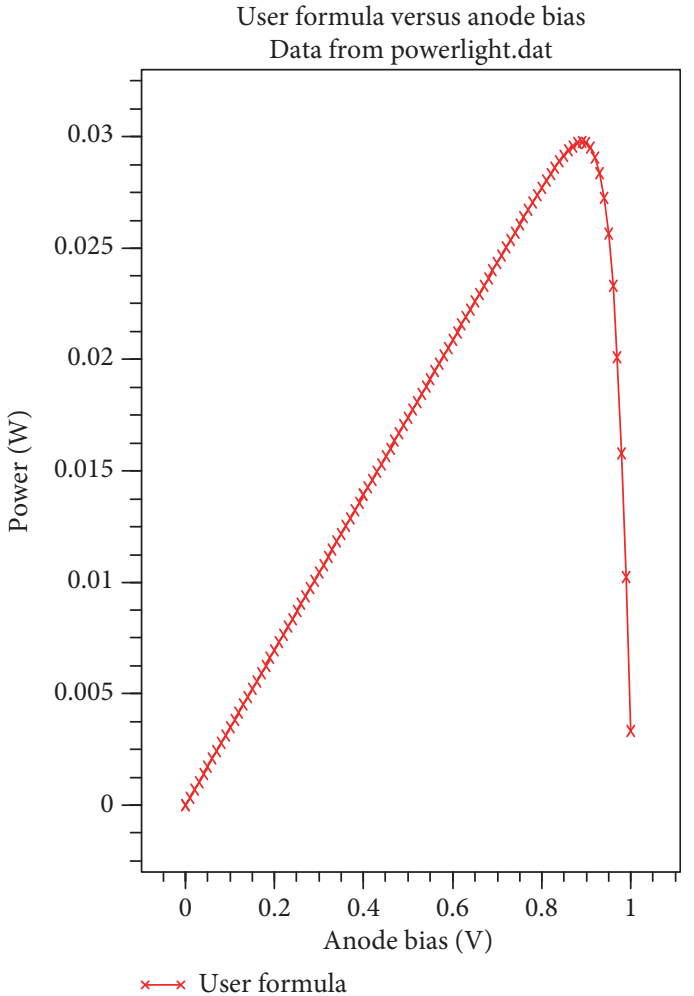

Figure 7: Power curve of the optimized solar cell.

TABLE 3: GA simulation parameters.

\begin{tabular}{lc}
\hline Parameters & Values \\
\hline Number of generations & $G=5$ \\
Population & $P=5$ \\
Crossover rate & $\mathrm{CR}=1.0$ \\
Mutation rate & $\mathrm{MR}=0.05$
\end{tabular}

TABle 4: Output power improvement.

\begin{tabular}{lcc}
\hline Parameters & $\begin{array}{c}\text { Original single } \\
\text { solar cell }\end{array}$ & $\begin{array}{c}\text { Optimized single } \\
\text { solar cell }\end{array}$ \\
\hline $\begin{array}{l}\text { Short-circuit current } \\
\left(I_{\mathrm{sc}}\right)(\mathrm{mA})\end{array}$ & 22.88 & 34.79 \\
$\begin{array}{l}\text { Open-circuit voltage } \\
\left(V_{\mathrm{oc}}\right)(\mathrm{V})\end{array}$ & 1.08 & 1 \\
Max current $\left(I_{\mathrm{mp}}\right)(\mathrm{mA})$ & 21.87 & 33.42 \\
Max voltage $\left(V_{\mathrm{mp}}\right)(\mathrm{V})$ & 0.96 & 0.89 \\
Fill Factor FF $(\%)$ & 84 & 85 \\
Maximum power $\left(P_{\max }\right)$ & 0.021 & 0.029 \\
$\left(\mathrm{~W} / \mathrm{cm}^{2}\right)$ & 21 & 29.7 \\
Efficiency $(\%)$ & &
\end{tabular}

are due to the variations in the material, optical parameters used, and optimization performance method presented in this work. Table 5 shows the various comparisons of this optimized structure with other previous publications; GaAs 


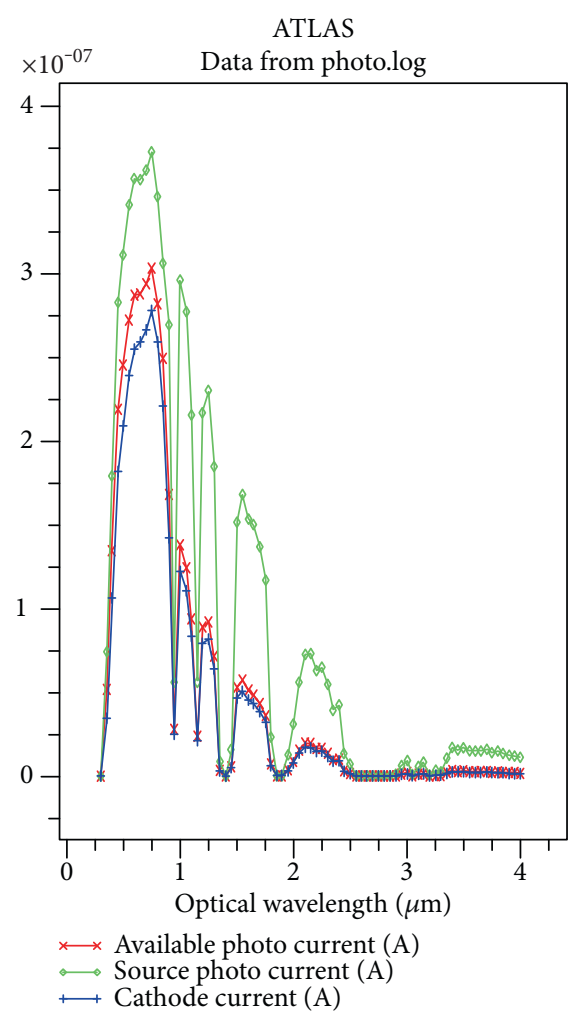

FIGURE 8: Generation of photocurrent by GaAs cell.

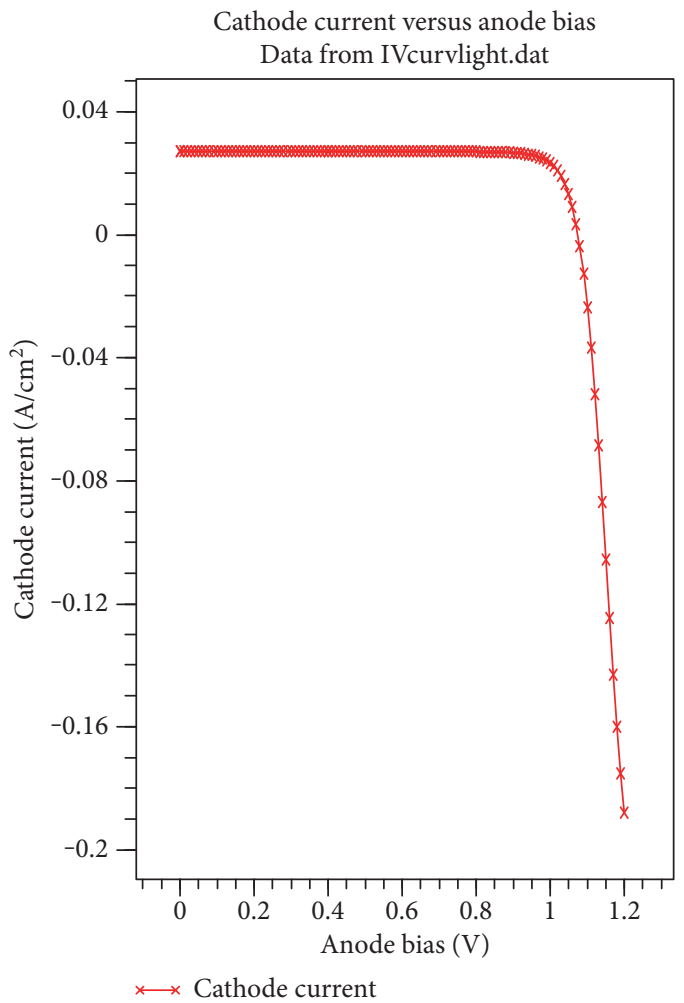

Figure 9: $I-V$ characteristics of the optimized solar cell.

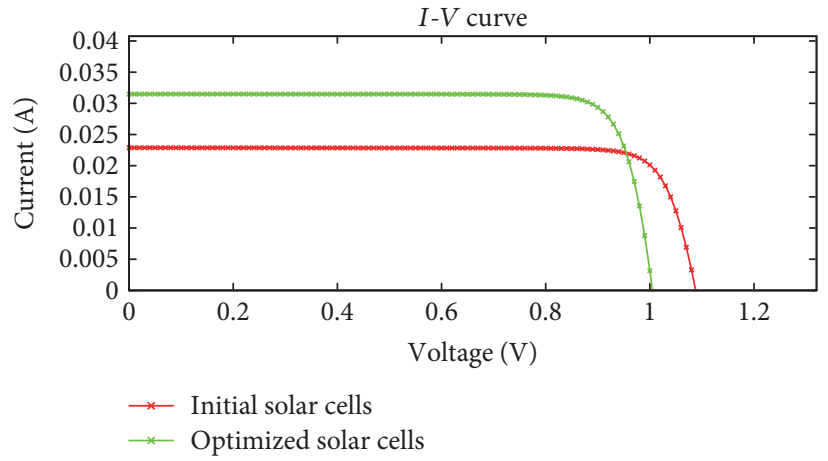

Figure 10: Comparison between the original and optimized $I-V$ characteristic solar cells.

TABLE 5: Comparison between our optimized GaAs solar cell and others cells from publications.

\begin{tabular}{lcccc}
\hline Publications & $J_{\mathrm{sc}}\left(\mathrm{mA} / \mathrm{cm}^{2}\right)$ & $V_{\mathrm{oc}}(\mathrm{V})$ & $\mathrm{FF}$ & $\eta(\%)$ \\
\hline Vandamme et al. [14] & 19.4 & 0.865 & 0.77 & 12.9 \\
Yang et al. [15] & 24.5 & 1.0 & 0.78 & 19.1 \\
Kayes et al. [16] & 29.7 & 1.122 & 0.87 & 28.8 \\
Lee et al. [17] & 22.0 & 0.942 & 0.78 & 16.2 \\
Moon et al. [18] & 27.06 & 0.98 & 0.83 & 22.08 \\
This work (initial structure) & 22.88 & 1.08 & 0.84 & 21 \\
$\begin{array}{l}\text { This work (optimized solar } \\
\text { cell) }\end{array}$ & 34.79 & 1.0 & 0.85 & 29.75 \\
\hline
\end{tabular}

solar cell achieves the highest efficiency as can be seen through the values $J_{\mathrm{sc}}=34.79 \mathrm{~mA} / \mathrm{cm}^{2}, \quad V_{\mathrm{oc}}=1 \mathrm{~V}$, and $\mathrm{FF}=85 \%$. Also, the close efficiency to our solar cell achieved $28.8 \%$ as can be seen in Table 5 by Kayes et al. [16]. Figure 8 shows the spectral response of the optimized solar cells. Figure 11 shows that the solar cell absorbs wavelength between 400 and $900 \mathrm{~nm}$. The overall efficiency of the optimized GaAs solar cell is shown in Figure 12 which is higher at $685 \mathrm{~nm}$ compared to $200 \mathrm{~nm}$ in the initial structure shown in Figure 1 for the emitter thickness and $2.95 \mu \mathrm{m}$ compared to $2 \mu \mathrm{m}$ for the base thickness in the same figures.

\section{Conclusion}

In this paper, a single GaAs solar cell was designed and optimized in two phases; the first was by building a structure with new layers like the buffer and the BSF that can significantly improve the performance due to higher collection of photogeneration minority carriers. We have proposed a new structure configuration based on GaAs that can achieve significant efficiency. Also in this work, a GA is applied and combined with the ATLAS code to increase our designed cell output power efficiency. The simulations shows that the efficiency improvement performance of the proposed GA is better than the initial proposed structure, and as result, an optimization of more than $8 \%$ is reached and new layer configuration is obtained as shown in Figure 12; in addition, it was compared 


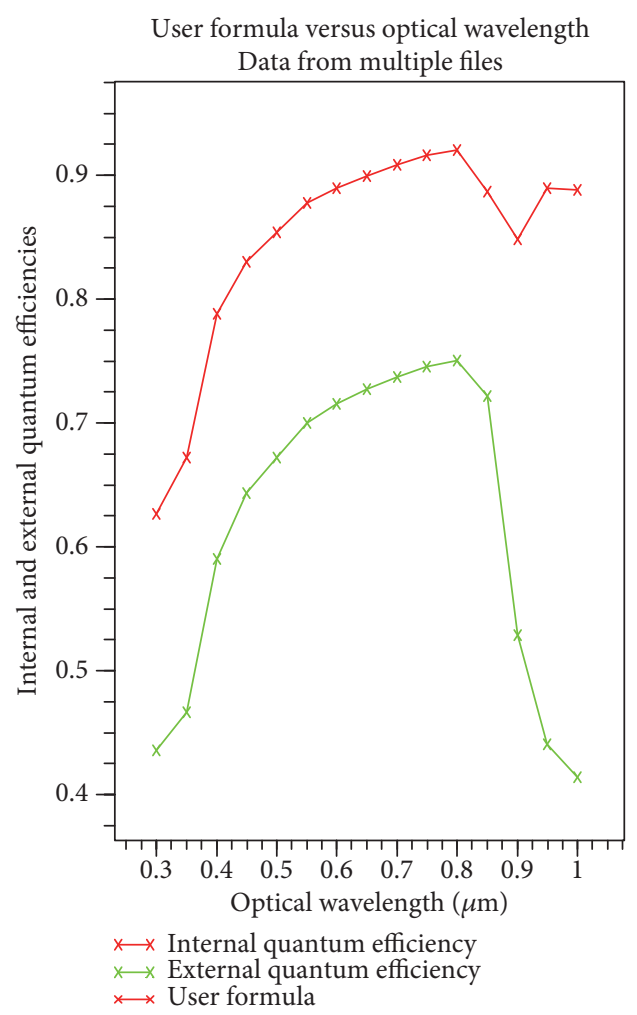

FIGURE 11: EQE and IQE of the optimized solar cells.

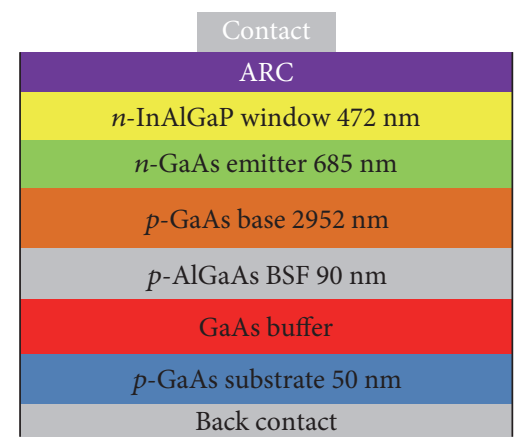

Figure 12: Schematic diagram of the optimized single solar cell structure.

to other single solar cells from previous publications. Its performance characteristics were $J_{\mathrm{sc}}=34.79 \mathrm{~mA} / \mathrm{cm}^{2}$, $V_{\mathrm{oc}}=1.0 \mathrm{~V}, \mathrm{FF}=85 \%$, and $\eta=29.75 \%$.

\section{Conflicts of Interest}

The authors declare that they have no conflicts of interest.

\section{Acknowledgments}

The authors acknowledge Mr. Karim Talhi for his help.

\section{References}

[1] J. Nelson, The Physics of Solar Cells, Imperial College Press, London, 2003.
[2] S. C. Tsaur, "Theoretical and experimental results for GaAs solar cells," in Proceedings of the Fourth International Symposium on GaAs and related compounds, conference series no. $17,1972$.

[3] J. J. Liou and W. W. Wong, "Comparison and optimization of the performance of $\mathrm{Si}$ and GaAs solar cells," Solar Energy Materials and Solar Cells, vol. 28, pp. 9-28, 1992.

[4] D. J. Aiken, "Antireflection coating design for series interconnected multi-junction solar cells," Progress in Photovoltaics: Research and Applications, vol. 8, p. 563, 2000.

[5] B. Galiana, I. ReyStolle, M. Baudrit, I. Garcia, and C. Algora, "A comparative study of BSF layers for GaAs-based singlejunction or multijunction concentrator solar cells," Semiconductor Science and Technology, vol. 21, pp. 1387-1393, 2006.

[6] K. J. Singha and S. K. Sarkar, "A wide band gap In $0.5(\mathrm{Al} 0.7 \mathrm{Ga} 0.3) 0.5 \mathrm{P}$ back surface field layer increases $6 \%$ more efficiency in DLAR dual junction InGaP solar cell," in 2016 International Conference on Energy Efficient Technologies for Sustainability (ICEETS), Nagercoil, India, 2016.

[7] K. Barnham, J. Barnes, G. Haarpainter et al., "Quantum-well solar cells," Materials Research Society Bulletin, vol. 18, pp. 51-55, 1993.

[8] A. Talhi, A. Belghachi, H. Moughli, B. Amiri, and L. Varani, "Numerical simulation of multi-quantum solar cells GaAs/ InAs using Silvaco Atlas," Digest Journal of Nanomaterials and Biostructures, vol. 11, pp. 1361-1366, 2016.

[9] K. J. Singh and S. K. Sarkar, "Highly efficient ARC less InGaP/ GaAs DJ solar cell numerical modeling using optimized InAlGaP BSF layers," Optical and Quantum Electronics, vol. 43, pp. 1-21, 2012.

[10] SILVACO Data Systems Inc, Silvaco ATLAS User's Manual, 2015.

[11] I. Vurgaftman, J. R. Meyer, and L. R. Ram-Mohan, "Band parameters for III-V compound semiconductors and their alloys," Journal of Applied Physics, vol. 89, no. 11, pp. 58155875, 2001.

[12] D. E. Aspnes, S. M. Kelso, R. A. Logan, and R. Bhat, "Optical properties of AlxGa1-xAs," Journal of Applied Physics, vol. 60 , no. 2, pp. 754-767, 1986.

[13] C. Guo, "A programming of genetic algorithm in Matlab7.0," Modern Applied Science, vol. 5, pp. 230-235, 2011.

[14] N. Vandamme, H. L. Chen, A. Gaucher et al., "Ultrathin GaAs solar cells with a silver back mirror," IEEE Journal of Photovoltaics, vol. 5, pp. 565-570, 2015.

[15] W. Yang, J. Becker, S. Liu et al., "Ultra-thin GaAs single junction solar cells integrated with a reflective back scattering layer," Journal of Applied Physics, vol. 115, article 203105, 2014.

[16] B. M. Kayes, N. Hui, R. Twist et al., " $27.6 \%$ conversion efficiency, a new record for single-junction solar cells under 1 sun illumination," in 2011 37th IEEE Photovoltaic Specialists Conference, pp. 000004-000008, Seattle, WA, USA, 2011.

[17] S. M. Lee, A. Kwong, D. Jung et al., "High performance ultrathin GaAs solar cells enabled with heterogeneously integrated dielectric periodic nanostructures," ACS Nano, vol. 9, pp. 10356-10365, 2015.

[18] S. Moon, K. Kim, Y. Kim, J. Heo, and J. Lee, "Highly efficient single-junction GaAs thin-film solar cell on flexible substrate," Scientific Reports, vol. 6, article 30107, 2016. 

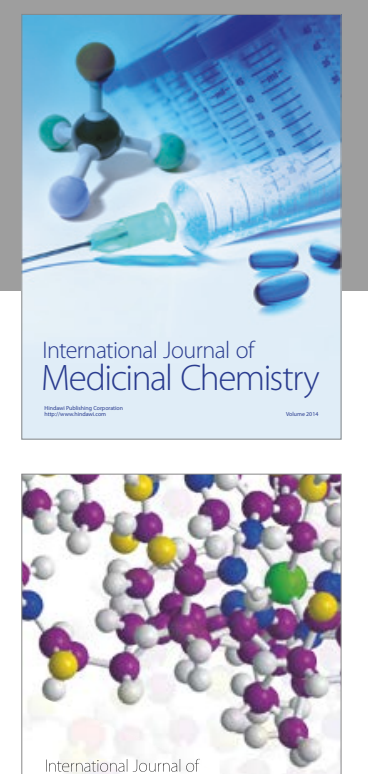

Carbohydrate Chemistry

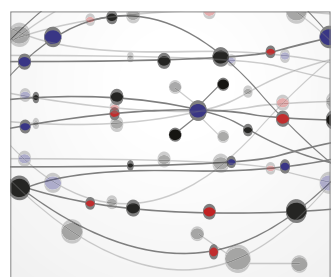

The Scientific World Journal
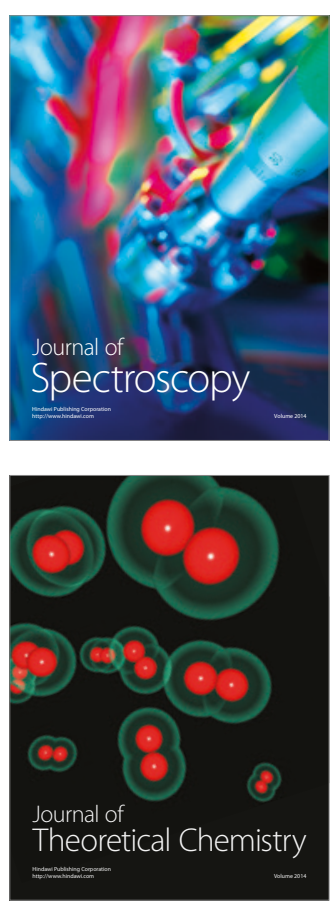
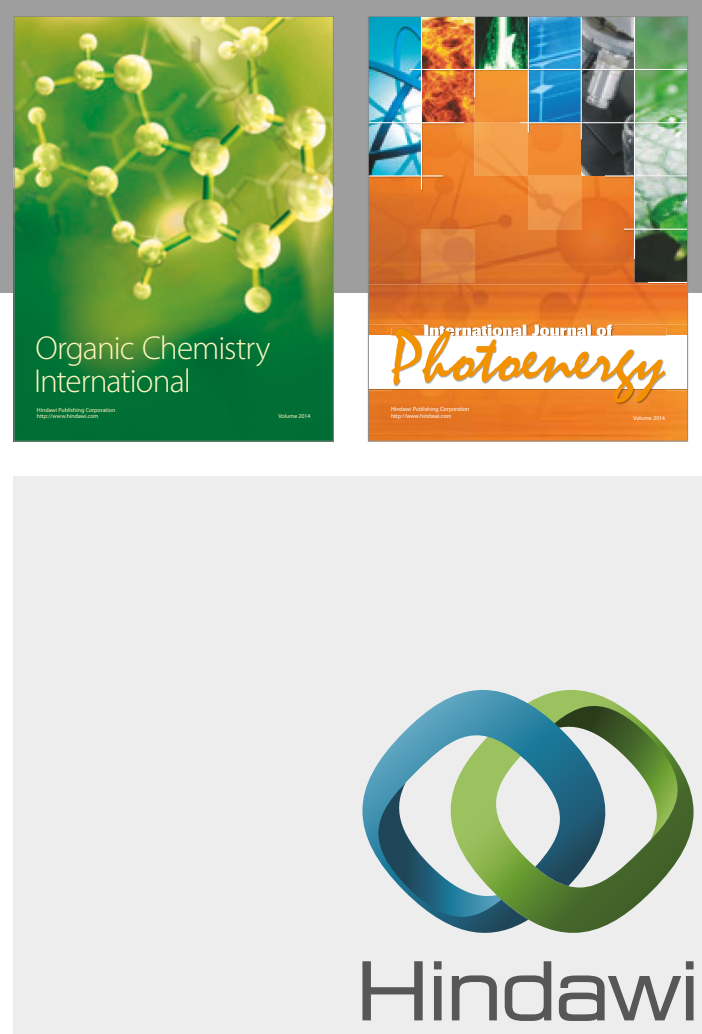

Submit your manuscripts at

https://www.hindawi.com

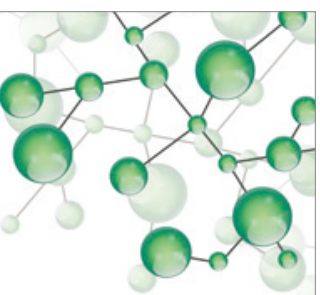

International Journal of

Inorganic Chemistry

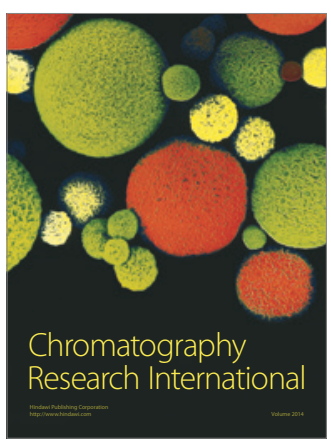

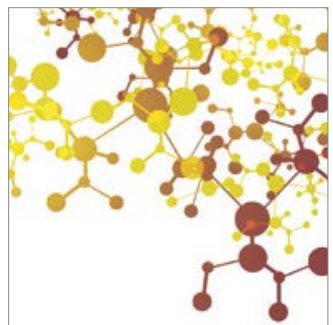

Applied Chemistry
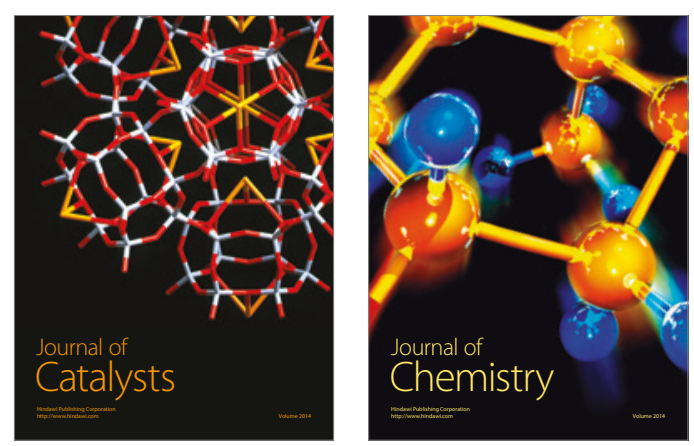
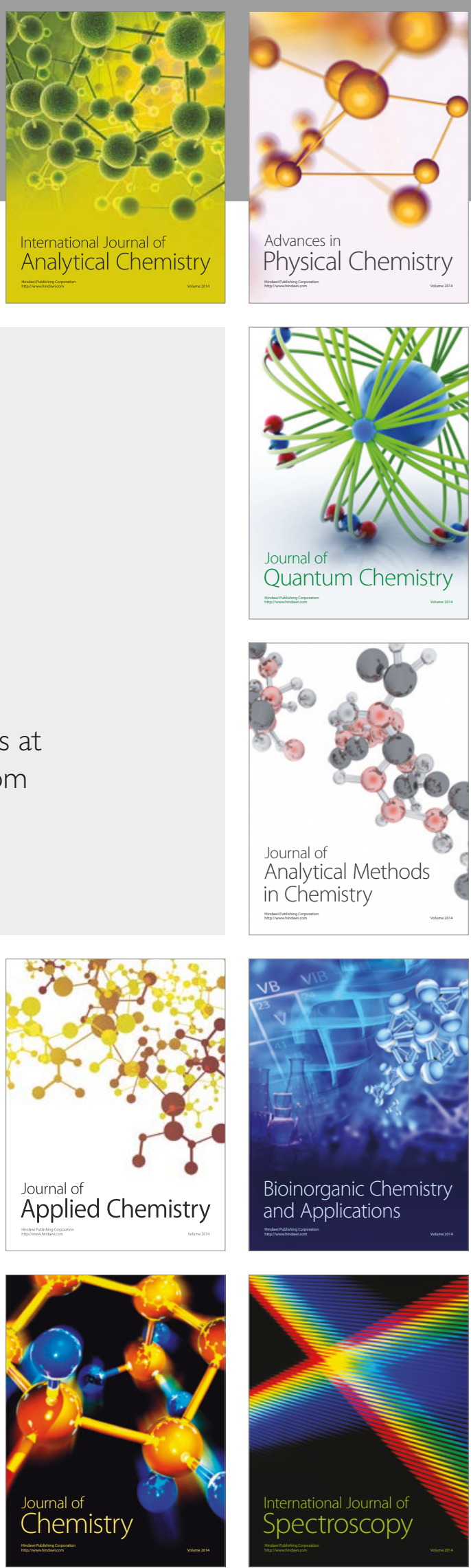